\title{
Non-uniform torsion of thin-walled open-section multi-span beams
}

\section{Стесненное кручение многопролетных тонкостенных балок открытого профриля}

\author{
A.D. Pavlenko, \\ V.A. Rybakov, \\ A.V. Pikht, \\ E.S. Mikhailov, \\ Peter the Great St. Petersburg Polytechnic \\ University, St. Petersburg, Russia
}

Key words: structural mechanics; light steel thinwalled structures; bending moment; bimoment; multi-span continuous thin-walled beams; frame system; beam deformation; normal stress; coefficient of proportionality; method by B.P.E. Clapeyron

\author{
Студент А.Д. Павленко, \\ канд. техн. наук, доцент В.А. Рыбаков, \\ студент А.В. Пихт, \\ студент Е.C. Михайлов, \\ Санкт-Петербургский политехнический \\ университет Петра Великого, г. Санкт- \\ Петербург, Россия
}

\author{
Ключевые слова: энергоэффективность; \\ коэффицциент теплотехнической \\ однородности; геометрический параметр; \\ сопротивление теплопередаче; ограждающая \\ конструкция здания; температурное поле; \\ теплота; термограмма; здание; \\ строительство
}

\begin{abstract}
In the article a calculation of the bending moment and bimoment for different occasions single- and multi-span continuous thin-walled channel section beams using B.P.E. Clapeyron and N.L. Kuzmin methods have been made. Article considers the cases of uniformly distributed loading with the eccentricity relative to the center line of the bend sections of one-, two-, three- and five-span beams with with spans 2.5 meters long and 5 meters. Ratio between the bending moment and bimoment in feature points and proportionality coefficients between the bending moment and bimoment has been calculated experimentally. Article suggests a formula that allows to determine bimoment, if only the bending moment and the eccentricity of applied load are given.

Аннотация. В статье выполнен расчет изгибающего момента и бимомента для разных случаев одно- и многопролетных неразрезных тонкостенных балок швеллерового сечения с использованием методов Б.П.Э. Клапейрона и Н.Л. Кузьмина. Рассмотрены случаи загружения равномерно распределенной нагрузкой с эксцентриситетом относительно линии центров изгиба сечений одно-, двух-, трех- и пятипролетной балок с пролетами: длиной 2,5 метров и 5 метров. Посчитаны отношения величин изгибающего момента и бимомента в характерных точках пролетов и определены коэффрициенты пропорциональности между изгибающим моментом и бимоментом. Предложена формула, позволяющая определить бимомент, зная лишь изгибающий момент и эксцентриситет приложения нагрузки.
\end{abstract}

\section{Introduction}

At the turn of XXI century in all over the earth metallurgy industry is quite actively developing. Today there is widespread application of metal structures in civil engineering. The main advantages of steel structures are universaly, strength and, at the same time, lightness. Moreover, these constructions are pre-fabricated, that is very important in construction.

The most profitable and effective way to construction of prefabricated structures is to use the system of light steel thin-walled structures (LSTS below), and also thermal insulation, facing and vapor sealing.

However, such a significant feature as lightness, can effect on the ability of constriction's bearing strength. So, testing and analysis of bearing strength of the product are necessary (especially for open sections, such as I-profiles and Z-profiles, angle and channel profiles).

Павленко А.Д., Рыбаков В.А., Пихт А.В., Михайлов Е.С. Стесненное кручение многопролетных тонкостенных балок открытого профиля // Инженерно-строительный журнал. 2016. № 7(67). С. 55-69. 
LSTS can be used as an economic variant in low-rise housing construction.

Despite the widespread application of LSTS, there are significant weaknesses in the standard and methodological bases of LSTS calculation.

To solve these problems, it is necessary to refer to the fundamental science - structural mechanics.

Cold-rolled thermoprofile and light thin galvanized sheet beams are the main elements of LSTS. Beams are used to build the frame of the building, and for the installation of individual elements.

The special shape of the profile ensures high durability of the product and makes on the thermal profile walls slots reduce heat loss and avoids the emergence of "cold bridges". [1]

In construction practice bending is the most common type of strain, which is more typical for beam structures. In most cases, share force occurs with the bending moment in the beams and that bending is called cross.

Normal stresses dominate in cross bend of thin-walled beams. It determines the bearing capacity of the beam.

The normal stress is a summation of longitudinal force acting, bending moments of two planes and bimoment acting.

Bimoment - additional force characteristic. It is self-balanced factor and it can not be found from equilibrium conditions of clipping part. Bimoment characterizes the changes, introduced in linear zones stress distribution of distortion of cross-section. It is a pair of bending moments applied in opposite directions, or the four forces, the action direction of two is not the same as the rest.

V.Z. Vlasov made a huge technical contribution to the thin beams theory development. He is considered as the founder of the theory. He suggested the formula of bimoment calculation for thinwalled metal-roll. His theory was developed and continued throughout the twentieth century by dozens of Russian scientists. S.P. Tymoshenko made a big contribution to the development of the thin-walled beams stability theory. Engineer E.N. Popova engaged the problem of accounting embossments in thinwalled profiles. [1]

A.R. Tusnin and M. Prokich examined the combined effect of bending moment and bimoment on I-profiles. They have given recommendations for determination their load-bearing capacity with the development of plastic deformations. [2]

N.L. Kuzmin, P.A. Lucash, I.E. Mileikovskii engaged the methods of bimoment and stresses calculation for multi-span beams, but they did not define the link between bimoment and bending moment. [3]

D.A. Trubina, L.A. Kononov, A.A. Kaur, E.D. Pichugin, D.A. Abdulaev in their article [5] examined various methods of thin-walled structures behaviour, and also determined the dependence of local stability of the cross-section of the various parameters and found the degree of influence on the intermediate amplifiers LPA wall.

V. Rybakov and O.S. Gamayunova in their article [6] provide an overview of the characteristics and problems of the stress-strain state (SSS) analysis of the thin-walled frame structures elements of open and closed profiles, and also some specific effects of their work, such as warping of the cross-section and the "bimomental" normal stress distribution over the cross section.

M.K. Bronzova, N.I. Vatin, M.R. Garifullin in their article [7] describe a new design of frame buildings using the skeleton of LSTS monolithic foam concrete.

M.R. Garifullin, N.I. Vatin considered domestic and foreign publications relating to cold-formed thinwalled profile, which works on a bend. [8]

T.V. Nazmeeva in her article [9] provides numerical and experimental study of bearing capacity of racks of various lengths from cold-formed C-profile solid and perforated section in order to obtain reliable methodology for their calculation.

A.S. Sinelnikov made a numerical analysis of the expanded stretching profile based on the finite element method, and conducted experimental and analytical studies. [10, 11]

In their work [13] V.V. Lalin, V.A. Rybakov have developed a numerical method for the calculation of thin-walled rod systems semi-shearing and unshearing theories calculation. [13] 
According to the researches [13-16] in thin-walled bar structures, which are subjected by bending torsion, component of normal stresses from bimoment can exceed component from bending moment and tangent strain effects on stress strain behavior small by the side of normal stresses. [4]

V.V. Lalin, V.A. Rybakov, S. Morozov in their publication reviewed test problems of non-uniform torsion of thin-walled beam with different boundary conditions. In the terms of the search static force factor in a non-uniform torsion were examined: bimoment, sectorial torque and moment of pure torsion. [17]

The article [18] considers the technology of multi-storey buildings construction using LSTS, and also offers the possibility of constructive solutions on the basis of existing projects. Article offers a comparison of LSTS with other materials used as cladding elements in buildings with high altitude. The main advantages and disadvantages of the application of light steel thin-walled structures in high-rise construction were showed in the issue.

The article [20] of A.R. Tusnin shows the features of calculation and design of thin-walled structures, which are widely used in construction. The numerical method of calculation of bar beam systems is considered.

In [21] free vibration analysis of thin-walled channel section beam including warping effects has been carried out using Finite element method and compared with experimentally measured results.

The arcticle [22] discusses the dynamics of a composite thin-walled box-beam built into a rigid hub and performing combined motion of rotation and in-plane translation.

The arcticle [23] showes that for the calculation of thin-walled structures considering restrained torsion can be successfully applied finite element method.

In [24] the crushing behavior of circular aluminum thin-walled tubes with functionally graded thickness (FGT) is investigated experimentally.

The lateral stability of bending non-prismatic thin walled beams is calculated using orthogonal Chebyshev series in the work [25].

This paper [26] investigates the effects of fatigue material data and finite element types on accuracy of residual life assessments under high cycle fatigue conditions.

The arcticle [27] presents an experimental study on the behaviors and modes of failure of square thin-walled steel tubed RC columns subjected to concentrically axial load applied directly to the RC core.

The purpose of this paper [28] is to resolve aforesaid problems and find out a kind of new technics substitute for present forming method.

According to available sources, bimoment is calculated by different formulas, depending on the type of design schemes. The disadvantage is in cumbersome formulas of the application of a hyperbolic sine and cosine. [4]

The goal of this article is to obtain a design proportionality coefficient (maximum) value of the bending moment and bimoment for multi-span beams with equal span, loaded with a uniformly distributed load equipartition, which will facilitate the difficult calculation of bimoment.

The objectives of the article - a function definition (diagrams) of the bending moment in the statically indeterminate single- and multi-span beams, including the method of B.P.E. Klapeyron and N.L. Kuzmin.

Павленко А.Д., Рыбаков В.А., Пихт А.В., Михайлов Е.С. Стесненное кручение многопролетных тонкостенных балок открытого профиля // Инженерно-строительный журнал. 2016. № 7(67). С. 55-69. 


\section{Methods}

Assume channel section of beam (Figure 1) with dimensions: $70 \mathrm{~mm}$ - width of a channel, $220 \mathrm{~mm}$ - height:

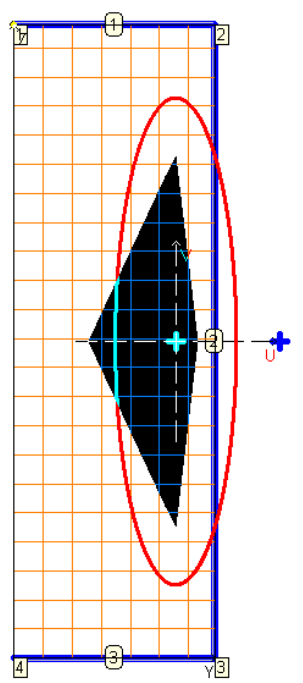

Figure 1. Cross-section of the beam under consideration in the program TONUS (SCAD Office)

Consider the calculation of bending moments and bimoment for the case of three-span beams (Figure 2), loaded with a uniformly distributed load $q=20 \mathrm{kN} / \mathrm{m}$, the length of each span I $=2.5 \mathrm{~m}$.

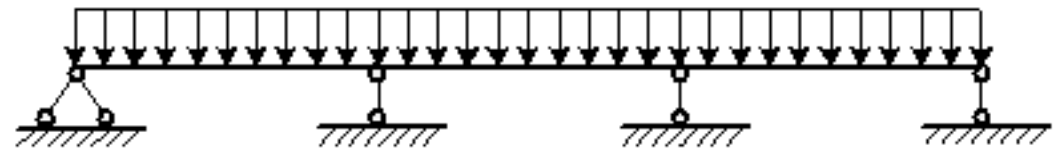

Figure 2. Design model

Define of values of bending moment, using the method of B.P.E. Clapeyron [4]: moments.

The value of the bending moment in the middle supports will be found with the equation of three

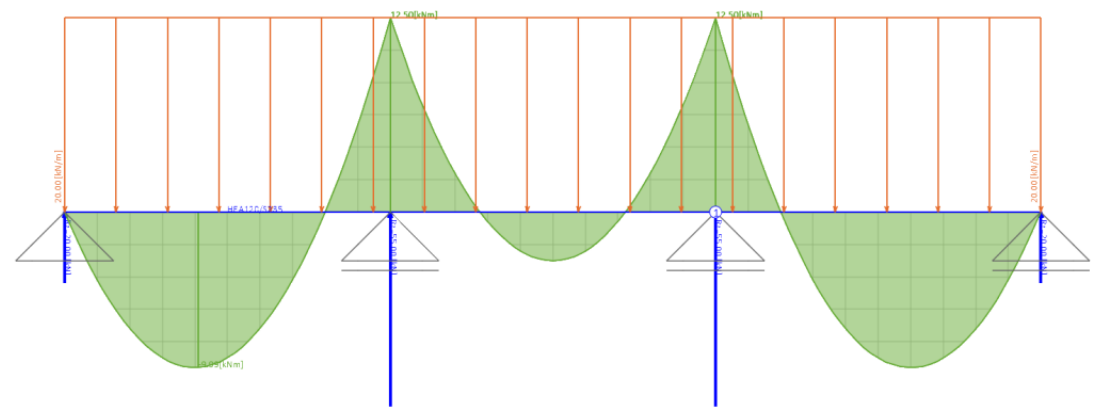

Figure 3. The bending moment $(\mathrm{kN} \cdot \mathrm{m})$ for the three-span beam

Finding bimoment is divided into four steps.

Consider bimoment value for each span of the uniformly distributed load, using (1) according to [3]:

$$
\mathrm{B}_{\mathrm{w}}=\frac{\mathrm{qe}}{\mathrm{k}^{2}}\left[1-\frac{\operatorname{chk}\left(\frac{\mathrm{l}_{1}}{2}-\mathrm{z}\right)}{\operatorname{ch} \frac{\mathrm{kl}_{1}}{2}}\right],
$$

where $z$ - horizontal coordinate of span varies from 0 to $2.5 \mathrm{~m}$, the eccentricity $\mathrm{e}$ is calculated by the formula (2): 


$$
\mathrm{e}=\frac{\mathrm{b}}{3}+\alpha
$$

where $\frac{b}{3}$ - raccepted position in the load center from the origin application center of wall channel gravity [1], $\mathrm{b}$ - the width of the channel, $\alpha$ - coordinate of the bending channel beams center found using a satellite program "TONUS" (SCAD Office). [19]

Flexural-torsional characteristics of response section $k$ will be found with the formula (3):

$$
\mathrm{k}=\sqrt{\frac{\mathrm{GI}_{\mathrm{d}}}{\mathrm{EI}_{\mathrm{w}}}}
$$

where the shear modulus steel is $\mathrm{G}=79.3 \cdot 10^{9} \mathrm{~Pa}$, elastic modulus steel is $\mathrm{E}=2 \cdot 10^{11} \mathrm{~Pa}$; torsional inertia moment $I_{d}=0.095 \mathrm{~cm}^{4}$ and sectorial inertia moment $I_{w}=2647.298 \mathrm{~cm}^{6}$. Geometric characteristics are defined in the "TONUS" program [19].

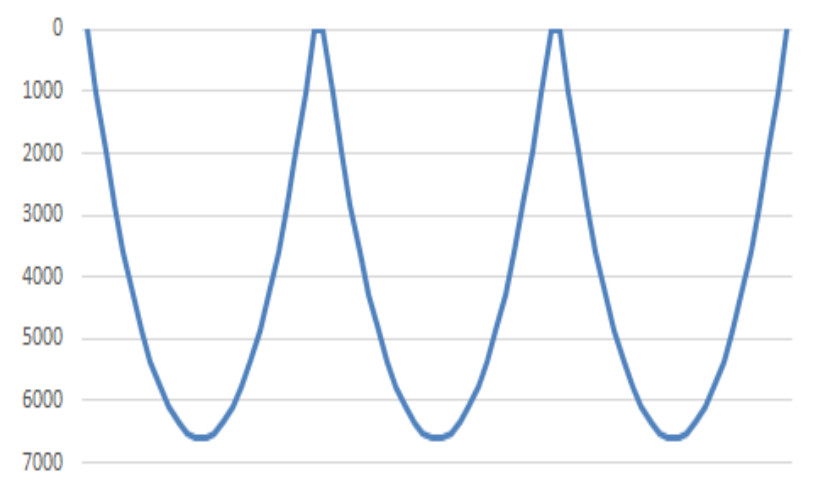

Figure 4. Diagram of bimoment $\left(\mathbf{k N} \cdot \mathrm{m}^{2}\right)$ from uniformly distributed load with eccentricity in each span

Define values of bimoment $B_{1}$ on supports, with using formula of three bimoments (4) [3]:

$$
B_{n-1} l_{n} \psi_{n}+2 B_{n}\left(l_{n} \varphi_{n}+l_{n+1} \varphi_{n+1}\right)+B_{n+1} l_{n+1} \psi_{n+1}=-6 E J_{\omega}\left(\bar{\theta}_{n+1}^{(\text {left })}-\bar{\theta}_{n+1}^{(\text {right })}\right),
$$

where $\psi_{n}$ and $\varphi_{n}$ - values, determined with interpolation method from table [3, p. 64], $\mathrm{n}$ - number of supports, $\theta_{n+1}$ - rotation angles on anchorages, determined with formula (5):

$$
\theta=-\frac{\mathrm{qe}}{\mathrm{k}^{3} \mathrm{E} \mathrm{J}_{\omega}}\left(\frac{\mathrm{kl}}{2}-\frac{\operatorname{sh} \frac{\mathrm{kl}}{2}}{\operatorname{ch} \frac{\mathrm{kl}}{2}}\right),
$$

Define bimoments for each span from determined bimoment $\mathrm{B}_{1}$, applied in the middle supports by formula (6):

$$
\mathrm{B}_{\overline{1}}=\mathrm{B}_{1} \frac{1}{2 \operatorname{ch} \frac{\mathrm{kl}_{1}}{2},}
$$

Павленко А.Д., Рыбаков В.А., Пихт А.В., Михайлов Е.С. Стесненное кручение многопролетных тонкостенных балок открытого профиля // Инженерно-строительный журнал. 2016. № 7(67). С. 55-69. 


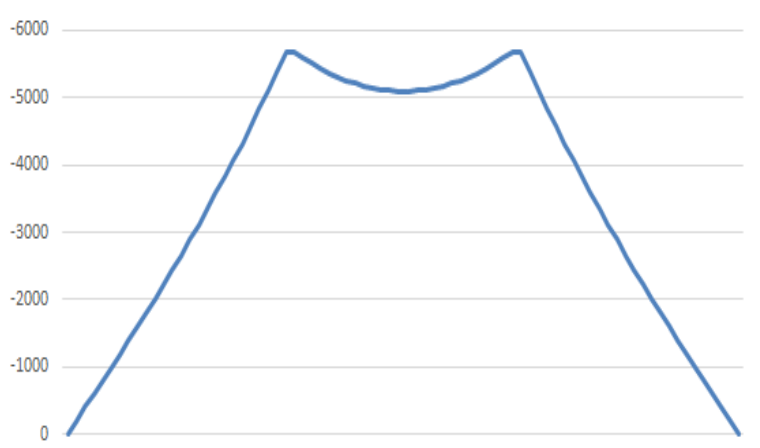

Figure 5. Diagram of bimoment $(\mathrm{kN} \cdot \mathrm{m} 2)$ from concentrated bimoments on anchorages

Conclusive diagram of bimomemnts frame as algebraical sum of couple diagrams (Figures 4 and 5)

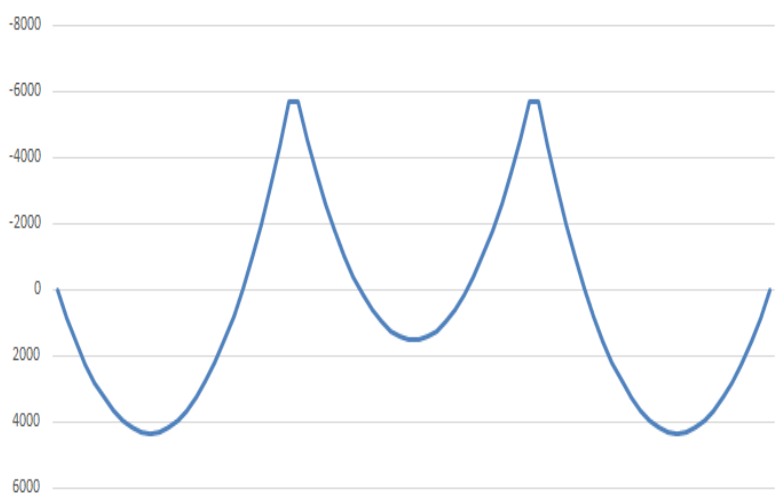

Figure 6. Conclusive diagram of bimoments $(\mathrm{kN} \cdot \mathrm{m} 2)$

\section{Comparison of bending moment diagrams and bimoment diagrams}

In the same way calculations were made for others modifications of analytical models and span's lengths. Analytical models and totals of calculations (diagram of bending moment and bimoment) were summarized in the Table 1.

As is seen from Figures 3-6, diagrams of bending moment and bimoment have similar configuration.

Suppose, that coversine of bimoment it is possible to express by coversine of bending moment using the proportionality coefficient.

To prove it, compare diagrams of bending moment and bimoment. 
Table 1. Diagrams of bending moment and bimoment for different single-span analytical models

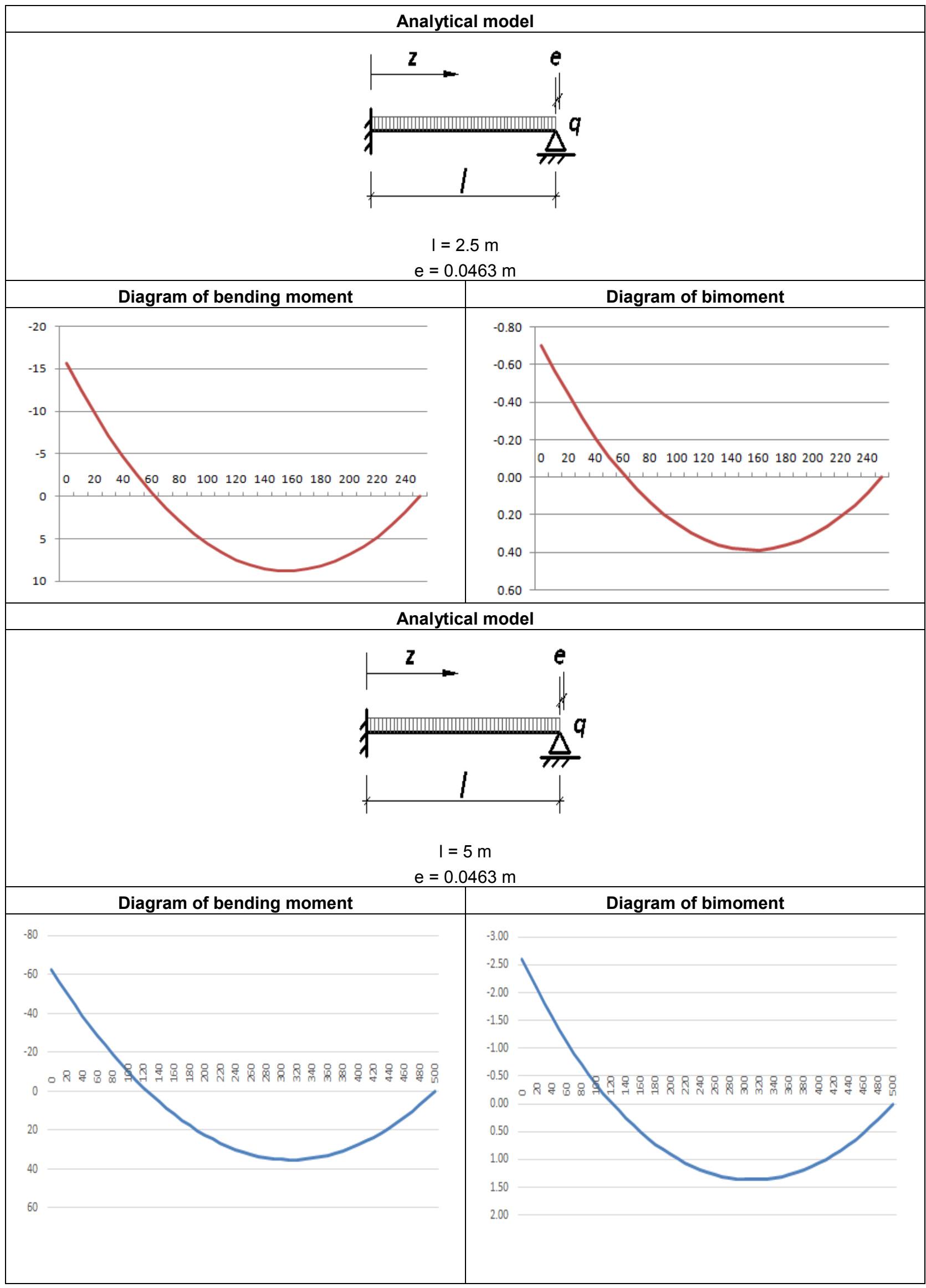

Павленко А.Д., Рыбаков В.А., Пихт А.В., Михайлов Е.С. Стесненное кручение многопролетных тонкостенных балок открытого профиля // Инженерно-строительный журнал. 2016. № 7(67). С. 55-69. 


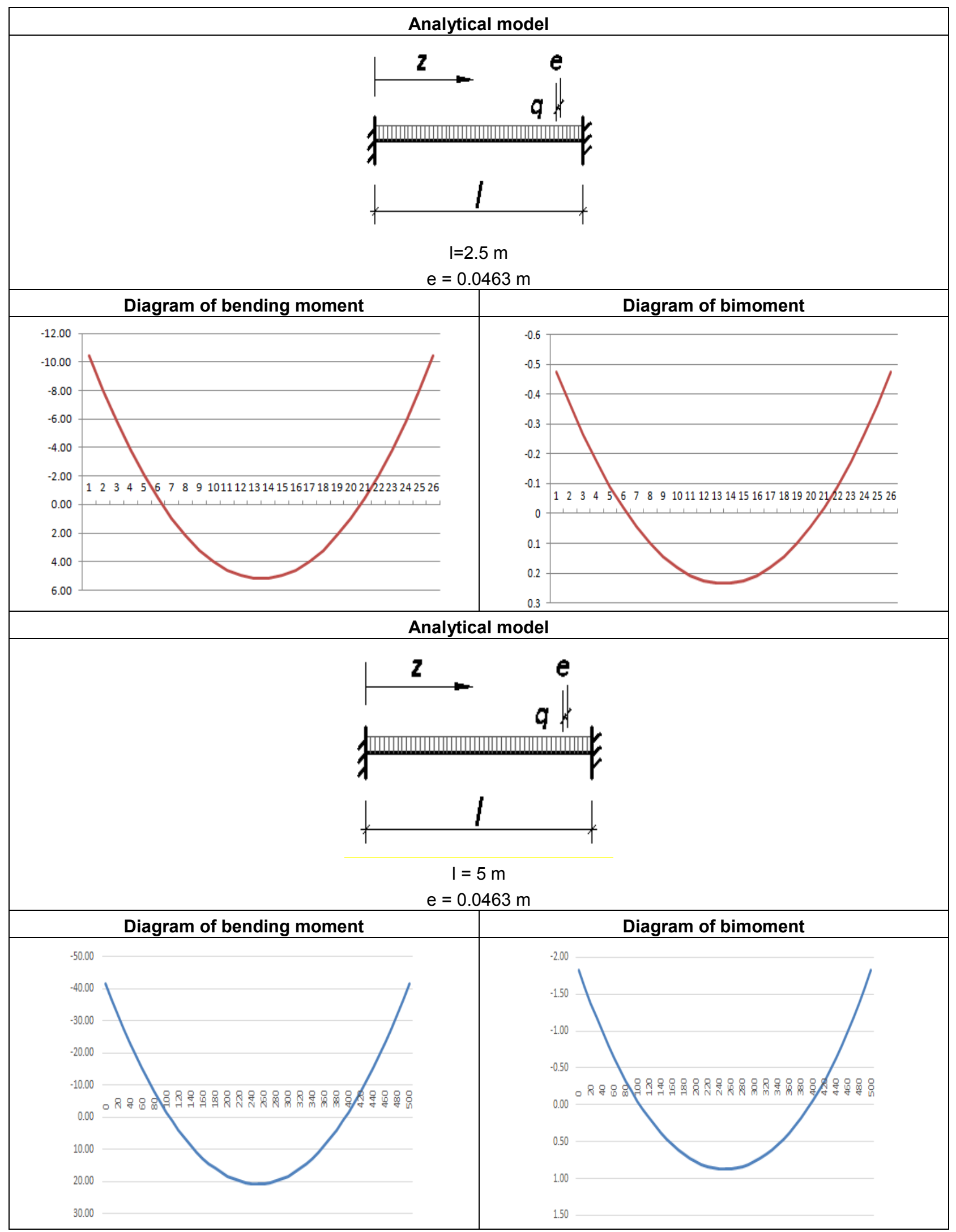

Pavlenko A.D., Rybakov V.A., Pikht A.V., Mikhailov E.S. Non-uniform torsion of thin-walled open-section multi- 
Инженерно-строительный журнал, № 7, 2016

Table 2. Diagrams of bending moment and bimoment for multi-span beams

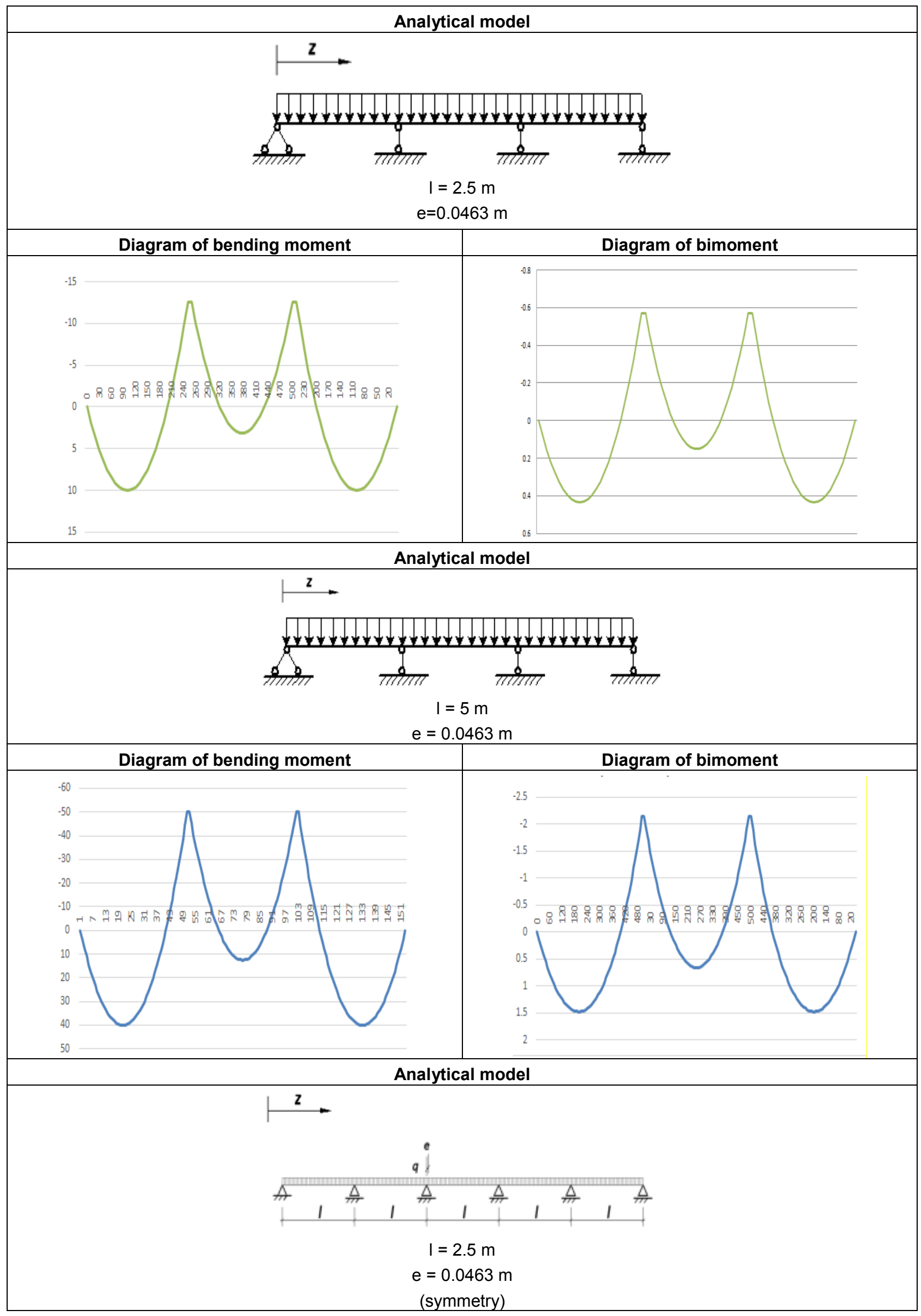

Павленко А.Д., Рыбаков В.А., Пихт А.В., Михайлов Е.С. Стесненное кручение многопролетных тонкостенных балок открытого профиля // Инженерно-строительный журнал. 2016. № 7(67). С. 55-69.

63 


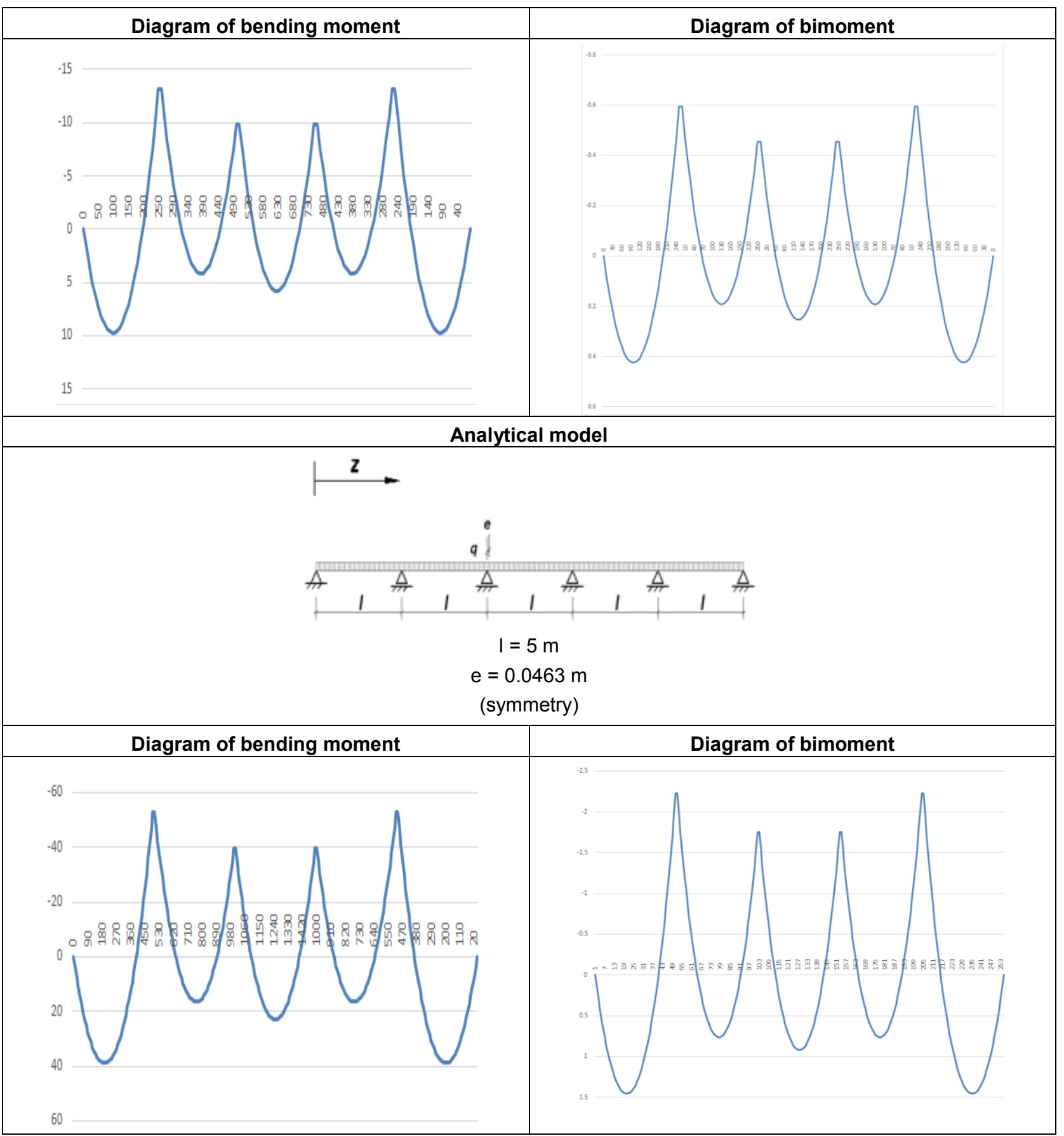

From Tables 1, 2 it appears, that diagrams of bending moment and bimoment really are alike both for single-span and for multi-span beams.

\section{Result and Discussion}

In Tables 3-5 bending moment and bimoment ratio present for beams with different number of spans ( 1,3 and 5 spans), span lengths ( 2.5 and 5 metres) and fixing type (fixed and hinged). 
Table 3. Values of bending moment and bimoment for single-span beams

\begin{tabular}{|c|c|c|c|}
\hline $\begin{array}{l}\text { Bending moment } \\
\text { (bimoment) }\end{array}$ & $\begin{array}{l}\text { Moment value in fixed } \\
\text { support } \\
(\mathrm{kN} \cdot \mathrm{m}) \\
\text { Bimoment value in fixed } \\
\text { support }\left(\mathrm{kN} \cdot \mathrm{m}^{2}\right) \\
\text { Moment and bimoment } \\
\text { ratio }\left(\mathrm{m}^{-1}\right)\end{array}$ & $\begin{array}{c}\text { Moment value in the } \\
\text { middle of span }(\mathrm{kN} \cdot \mathrm{m}) \\
\text { Bimoment value in the } \\
\text { middle of span }\left(\mathrm{kN} \cdot \mathrm{m}^{2}\right) \\
\text { Moment and bimoment } \\
\text { ratio }\left(\mathrm{m}^{-1}\right)\end{array}$ & $\begin{array}{c}\text { Moment value in point of } \\
\text { local extremum }(\mathrm{kN} \cdot \mathrm{m}) \\
\text { Bimoment value in point } \\
\text { of local extremum } \\
\left(\mathrm{kN} \cdot \mathrm{m}^{2}\right) \\
\text { Moment and bimoment } \\
\text { ratio }\left(\mathrm{m}^{-1}\right)\end{array}$ \\
\hline \multirow{2}{*}{$\stackrel{z}{\longrightarrow} \Delta^{q}$} & -15.63 & 7.81 & $8.78(z=1.6 \mathrm{~m})$ \\
\hline & -0.70 & 0.346 & $0.39(z=1.6 \mathrm{~m})$ \\
\hline $\begin{array}{c}1 \\
I=2.5 \mathrm{~m} ; \mathrm{e}=0.0463 \mathrm{~m}\end{array}$ & 22.23 & 22.56 & $22.64(z=1.6 \mathrm{~m})$ \\
\hline Coefficient value $k$ & 0.967 & 0.957 & 0.959 \\
\hline$z$ & -62.50 & 31.25 & $35.15(z=3.1 \mathrm{~m})$ \\
\hline & -2.60 & 1.23 & $1.36(z=3.1 \mathrm{~m})$ \\
\hline $\mathrm{I}=5 \mathrm{~m} ; \mathrm{e}=0.0463 \mathrm{~m}$ & 24.05 & 25.45 & $25.77(z=3.1 \mathrm{~m})$ \\
\hline Coefficient value $k$ & 0.898 & 0.850 & 0.914 \\
\hline $\begin{array}{l}\text { Bending moment } \\
\text { (bimoment) }\end{array}$ & $\begin{array}{c}\text { Moment value in fixed } \\
\text { support at the left }(\mathrm{kN} \cdot \mathrm{m}) \\
\text { Bimoment value in fixed } \\
\text { support at the left } \\
\left(\mathrm{kN} \cdot \mathrm{m}^{2}\right) \\
\text { Moment and bimoment } \\
\text { ratio }\left(\mathrm{m}^{-1}\right)\end{array}$ & $\begin{array}{c}\text { Moment value in the } \\
\text { middle of span }(\mathrm{kN} \cdot \mathrm{m}) \\
\text { Bimoment value in the } \\
\text { middle of span }\left(\mathrm{kN} \cdot \mathrm{m}^{2}\right) \\
\text { Moment and bimoment } \\
\text { ratio }\left(\mathrm{m}^{-1}\right)\end{array}$ & $\begin{array}{c}\text { Moment value in fixed } \\
\text { support at the right } \\
(\mathrm{kN} \cdot \mathrm{m}) \\
\text { Bimoment value in fixed } \\
\text { support at the right } \\
\left(\mathrm{kN} \cdot \mathrm{m}^{2}\right) \\
\text { Moment and bimoment } \\
\text { ratio }\left(\mathrm{m}^{-1}\right)\end{array}$ \\
\hline 2 & -10.42 & 5.21 & -10.42 \\
\hline 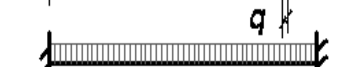 & -0.48 & 0.24 & -0.48 \\
\hline $\begin{array}{c}1 \\
I=2.5 \mathrm{~m} ; \mathrm{e}=0.0463 \mathrm{~m}\end{array}$ & 21.94 & 22.17 & 21.94 \\
\hline Coefficient value $k$ & 0.995 & 0.995 & 0.995 \\
\hline 2 & -41.67 & 20.83 & -41.67 \\
\hline 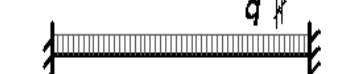 & -1.82 & 0.87 & -1.82 \\
\hline$\frac{1}{I=5 \mathrm{~m} ; \mathrm{e}=0.0463 \mathrm{~m}}$ & 22.85 & 23.86 & 22.85 \\
\hline Coefficient value $k$ & 0.943 & 0.902 & 0.943 \\
\hline
\end{tabular}

Analysis for similarity coversines bending moment and bimoment for multispan beams view values in feature points (maximum values; values in middle of spans and values on intermediate supports).

Павленко А.Д., Рыбаков В.А., Пихт А.В., Михайлов Е.С. Стесненное кручение многопролетных тонкостенных балок открытого профиля // Инженерно-строительный журнал. 2016. № 7(67). С. 55-69. 
Table 4. Values of bending moment and bimoment for three-span beams

\begin{tabular}{|c|c|c|c|c|c|c|c|}
\hline $\mathbf{z}$ & $\begin{array}{c}z= \\
1.0 \mathrm{~m}\end{array}$ & $\begin{array}{c}z= \\
1.25 \mathrm{~m}\end{array}$ & $\begin{array}{c}z= \\
2.5 \mathrm{~m}\end{array}$ & $\begin{array}{c}z= \\
3.75 \mathrm{~m}\end{array}$ & $\begin{array}{c}z= \\
5.0 \mathrm{~m}\end{array}$ & $\begin{array}{c}z= \\
6.25 \mathrm{~m}\end{array}$ & $\begin{array}{c}z= \\
6.5 \mathrm{~m}\end{array}$ \\
\hline$\longmapsto z$ & 10.00 & 9.38 & -12.50 & 3.13 & -12.50 & 9.38 & 10.00 \\
\hline $\begin{array}{l}\text { I } \\
\mathrm{I}=2.5 \mathrm{~m} ; \mathrm{e}=0.0463 \mathrm{~m}\end{array}$ & 0.43 & 0.41 & -0.57 & 0.15 & -0.57 & 0.41 & 0.43 \\
\hline Moment and bimoment ratio & 23.01 & 23.03 & 22.02 & 20.56 & 22.02 & 23.03 & 23.01 \\
\hline Coefficient value $\mathrm{k}$ & 0.929 & 0.944 & 0.985 & 1.035 & 0.985 & 0.944 & 0.929 \\
\hline $\mathbf{z}$ & $\begin{array}{c}z= \\
2.0 \mathrm{~m}\end{array}$ & $\begin{array}{c}z= \\
2.5 \mathrm{~m}\end{array}$ & $\begin{array}{c}z= \\
5.0 \mathrm{~m}\end{array}$ & $\begin{array}{c}z= \\
7.5 \mathrm{~m}\end{array}$ & $\begin{array}{c}z= \\
10.0 \mathrm{~m}\end{array}$ & $\begin{array}{c}z= \\
12.5 \mathrm{~m}\end{array}$ & $\begin{array}{c}z= \\
13.0 \mathrm{~m}\end{array}$ \\
\hline$\vdash z$ & 40.00 & 37.50 & -50.00 & 12.50 & -50.00 & 37.50 & 40.00 \\
\hline 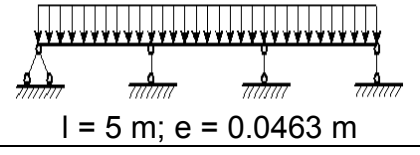 & 1.48 & 1.38 & -2.14 & 0.66 & -2.14 & 1.38 & 1.48 \\
\hline Moment and bimoment ratio & 27.09 & 27.15 & 23.32 & 19.05 & 23.32 & 27.15 & 27.09 \\
\hline Coefficient value $\mathrm{k}$ & 0.799 & 0.795 & 0.924 & 1.140 & 0.924 & 0.795 & 0.799 \\
\hline
\end{tabular}

Table 5. Values of bending moment and bimoment for five-span beams

\begin{tabular}{|c|c|c|c|c|c|c|}
\hline \multicolumn{7}{|c|}{ Analitical model } \\
\hline \multicolumn{7}{|c|}{ i } \\
\hline \multicolumn{7}{|c|}{$1 \stackrel{\Delta}{m} 1^{\#} 1^{\stackrel{\Delta}{\mid}} 1^{\stackrel{\Delta}{\mid}}$} \\
\hline \multicolumn{7}{|c|}{$\begin{array}{l}I=2.5 \mathrm{~m} \\
\mathrm{e}=0.0463 \mathrm{~m} \\
\text { (symmetry) }\end{array}$} \\
\hline$z=1.0 \mathrm{~m}$ & $z=1.25 \mathrm{~m}$ & $z=2.5 \mathrm{~m}$ & $z=3.75 \mathrm{~m}$ & $z=3.8 \mathrm{~m}$ & $z=5.0 \mathrm{~m}$ & $z=6.25 \mathrm{~m}$ \\
\hline 9.74 & 9.05 & -13.16 & 4.11 & 4.17 & -9.87 & 5.76 \\
\hline 0.43 & 0.39 & -0.59 & 0.19 & 0.19 & -0.45 & 0.25 \\
\hline \multicolumn{7}{|c|}{ Moment and bimoment ratio } \\
\hline 22.91 & 22.91 & 22.13 & 21.51 & 21.63 & 21.74 & 22.65 \\
\hline \multicolumn{7}{|c|}{ Coefficient value $k$} \\
\hline 0.954 & 0.931 & 0.968 & 0.998 & 0.984 & 0.985 & 0.937 \\
\hline \multicolumn{7}{|c|}{ Analitical model } \\
\hline \multicolumn{7}{|c|}{$z=$} \\
\hline \multicolumn{7}{|c|}{$A 1^{\stackrel{\Delta}{m}} 1^{\frac{\Delta}{m}} 1^{\frac{\Delta}{m}} 1^{\frac{\Delta}{m}} 1^{\frac{\Delta}{m}}$} \\
\hline \multicolumn{7}{|c|}{$\begin{array}{c}\text { I = } 5 \mathrm{~m} ; \\
\mathrm{e}=0.0463 \mathrm{~m} \\
\text { (symmetry) }\end{array}$} \\
\hline$z=2.0 \mathrm{~m}$ & $z=2.25 \mathrm{~m}$ & $\mathrm{z}=5.0 \mathrm{~m}$ & $\mathrm{z}=7.5 \mathrm{~m}$ & $\mathrm{z}=7.6 \mathrm{~m}$ & $z=10.0 \mathrm{~m}$ & $z=12.5 \mathrm{~m}$ \\
\hline 29.47 & 36.18 & -52.65 & 16.43 & 16.59 & -39.50 & 23.00 \\
\hline 1.12 & 1.35 & -2.23 & 0.76 & 0.76 & -1.75 & 0.92 \\
\hline \multicolumn{7}{|c|}{ Moment and bimoment ratio } \\
\hline 26.41 & 26.73 & 23.64 & 21.60 & 21.70 & 22.52 & 24.99 \\
\hline \multicolumn{7}{|c|}{ Coefficient value $k$} \\
\hline 0.821 & 0.806 & 0.915 & 0.999 & 0.989 & 0.957 & 0.864 \\
\hline
\end{tabular}

Pavlenko A.D., Rybakov V.A., Pikht A.V., Mikhailov E.S. Non-uniform torsion of thin-walled open-section multi- 
Analogous research was made by A.M.Sergei in his master's thesis [4]. It was considered an approximation of the theoretical relationships between bimoment and bending moment in a general way. He offered number of coefficients and tables that allows framing a diagram of bimoment by using the diagrams of the bending moment. However, from the practical point of view, the proposed communication continues to be complex and time-consuming for routine engineering tasks.

\section{Conclusions}

1. Values of bending moments and bimoments were determined for typically using analytical models and span's lengths.

2. It was established, that bimoment value is directly-proportional of bending moments values for the same spans and cross-sections; proportionality factor is eccentricity e of load application.

3. It was established, that ratio values of bending moment and bimoment change from 0.929 to 1.035 for span with length 2.5 metres, from 0.795 to 1.14 - for span with length 5 metres in case of single eccentricity for typically widespread spans $(2.5 \mathrm{~m} \ldots 5 \mathrm{~m})$.

4. It was recommended the dependence:

$$
B_{w}=M \cdot e \cdot k,
$$

where $\mathrm{k}$ - proportionality factor, determined according to the Tables $2-4$.

The set dependence allows determining bimoment value quickly in feature points of the span, knowing bending moment, eccentricity of load application, and also coefficient k, given from tables.

\section{References}

1. Rybakov V.A. Osnovy stroitelnoy mekhaniki legkikh stalnykh tonkostennykh konstruktsiy [Fundamentals of structural mechanics of light steel thin-walled structures]. Saint-Petersburg: Publishing Polytechnic University. 2011. 207 p. (rus)

2. Tusnin A.R., Prokic M. Rabota simmetrichnykh dvutavrovykh secheniy pri razvitii plasticheskikh deformatsiy i deystvii izgibayushchego momenta i bimomenta [Behavior of symmetric steel I-sections under combined bending and torsion actions allowing for plastic deformations]. Magazine of Civil Engineering. 2014. No. 5. Pp. 44-53.(rus)

3. Kuzmin N.L., Lucas P.A., Mileykovskaya I.E. Raschet konstruktsiy iz tonkostennykh strezhney $i$ obolochek [Structural analysis of thin-walled rods and shells]. Moscow: State publishing of literature on construction. 1960. 266 p. (rus)

4. Sergei A.M. Stesnennoe kruchenie mnogoproletnykh tonkostennykh balok otkrytogo secheniya [Constrained torsion of thin-walled multi-span beams of open section] Master's thesis. Peter the Great St.Peterburg Polytechnic University. 2015. 85 p. (rus)

5. Trubina D.A. , Kononova L.A., Kaurov A.A., Pichugin Y.D., Abdulaev D.A. Mestnaya poterya ustoychivosti stalnykh kholodnognutykh profiley $v$ usloviyakh poperechnogo izgiba [Local buckling of steel cold-formed profiles under transverse bending]. Construction of Unique Buildings and Structures. 2014. No. 4. Pp. 109-127. (rus)

6. Rybakov V.A., Gamayunova O.S. Napryazhennodeformirovannoe sostoyanie elementov karkasnykh sooruzheniy iz tonkostennykh sterzhney [The stress-strain state of frame constructions' elements from thin-walled cores]. Construction of Unique Buildings and Structures. 2013. No. 7. Pp. 79-123. (rus)

7. Bronzova M.K., Vatin N.I., Garifullin M.R. Konstruktsiya karkasnykh zdaniy $\mathrm{s}$ primeneniem monolitnogo penobetona [Frame buildings construction using monolithic foamed concrete]. Construction of Unique Buildings and Structures. 2015. No. 1. Pp. 74-90. (rus)

8. Garifullin M.R., Vatin N.I. Ustoychivost tonkostennogo kholodnognutogo profilya pri izgibe - kratkiy obzor

\section{Литература}

1. Рыбаков В.А. Основы строительной механики легких стальных тонкостенных конструкций. СПб.: Изд-во Политехн. ун-та, 2011. 207 с.

2. Туснин А.Р., Прокич М. Работа симметричных двутавровых сечений при развитии пластических деформаций и действии изгибающего момента и бимомента // Инженерно-строительный журнал. 2014 № 5(49). С. 44-53

3. Кузьмин Н.Л., Лукаш П.А., Милейковский И.Е. Расчет конструкций из тонкостенных стержней и оболочек. М. Госстройиздат, 1960. 266 с.

4. Сергей А.М. Стеснённое кручение многопролётных тонкостенных балок открытого сечения: диссертация на соискание квалификации магистра техники и технологии строительства. Санкт-Петербургский политехнический университет Петра Великого, 2015. 85 стр.

5. Трубина Д.А., Кононова Л.А.,. Кауров А.А, Пичугин Е.Д. Абдулаев Д.А.. Местная потеря устойчивости стальных холодногнутых профилей в условиях поперечного изгиба // Строительство уникальных зданий и сооружений. 2014. № 4(19). С. 109-127.

6. Рыбаков В.А., Гамаюнова О.С. Напряженнодеформированное состояние элементов каркасных сооружений из тонкостенных стержней // Строительство уникальных зданий и сооружений". 2013. № 7(12). C. 79-123.

7. Бронзова М.К., Ватин Н.И., Гарифуллин М.Р Конструкция каркасных зданий с применением монолитного пенобетона // Строительство уникальных зданий и сооружений. 2015. № 1(28). С. 74-90.

8. Гарифуллин М.Р., Ватин Н.И. Устойчивость тонкостенного холодногнутого профиля при изгибе краткий обзор публикаций // Строительство уникальных зданий и сооружений. 2014. № 6(21). C. 32-57.

9. Назмеева Т.В. Несущая способность сжатых стальных тонкостенных элементов сплошного и перфорированного сечения из холодногнутого Спрофиля // Инженерно-строительный журнал. 2015.

Павленко А.Д., Рыбаков В.А., Пихт А.В., Михайлов Е.С. Стесненное кручение многопролетных тонкостенных балок открытого профиля // Инженерно-строительный журнал. 2016. № 7(67). С. 55-69. 
publikatsiy [Buckling analysis of thin-walled cold-formed beams - short review]. Construction of Unique Buildings and Structures. 2014. No. 6. Pp. 32-57. (rus)

9. Nazmeeva T.V. Nesushchaya sposobnost szhatykh stalnykh tonkostennykh elementov sploshnogo perforirovannogo secheniya iz kholodnognutogo C-profilya [Bearing capacity of compressed continuous and perforated thin-walled steel members of C-shaped coldformed profiles]. Magazine of Civil Engineering. 2015. No. 5. Pp. 44-51. (rus)

10. Sinelnikov A.S., Orlova A.V. Prochnost prosechnorastyazhnogo profilya: ispytaniya i matematicheskoe modelirovanie [Strength of the expanded stretching profile: tests and mathematical modeling]. Vestnik MGSU. 2013. No. 12. Pp. 41-54. (rus)

11. Lalin V.V., Rybakov V.A. Konechnye elementy dlya rascheta ograzhdayushchikh konstruktsiy iz tonkostennykh profiley [The finite elements for desing of building walling made of thin-walled beams]. Magazine of Civil Engineering. 2011. No. 8. Pp. 69-80. (rus)

12. Sovetnikov D.O., Videnkov N.V., Trubina D.A Tekhnologiya legkikh stalnykh tonkostennykh konstruktsiy [Light gauge steel framing in construction of multi-storey buildings]. Construction of Unique Buildings and Structures. 2015. No. 3. Pp. 152-165. (rus)

13. Airumyan E.L., White G.I. Issledovanie raboty stalnoy fermy iz kholodnognutykh profiley s uchetom ikh mestnoy i obshchey ustoychivosti [Study of the steel trusses from cold-formed profiles based on their local and Genera stability]. Industrial and Civil Engineering. 2010. No. 5. Pp. 41-44. (rus)

14. Perel'muter A.V., Slivker V.I. Ustoychivost ravnovesiya konstruktsiy $i$ rodstvennye problemy [Stability of equilibrium of structures and related problems]. Moscow: SKAD SOFT. 672 p. (rus)

15. Ayrumyan E.L., Kamenshchikov N.I. Ramnye konstruktsii stalnogo karkasa iz otsinkovannykh gnutykh profiley dlya odnoetazhnykh zdaniy razlichnogo naznacheniya [Frame structure of steelwork from zinc molded sections for onestorey buildings of different purposes]. World of property development. 2006. №. 36. Pp. 9-11. (rus)

16. Lalin V.V., Rybakov V.A., Morozov S.A. Issledovanie konechnykh elementov dlya rascheta tonkostennykh sterzhnevykh sistem [The Finite Elements Research for Calculation of Thin-Walled Bar Systems]. Magazine of Civil Engineering. 2012. No. 1. Pp. 53-73. (rus)

17. Karpilovskiy V.S., Kriksunov E.Z., Perelmuter A.V., Perelmuter M.A. SCAD for user. Kiev: VVP: "Compass", 2000. 332 p.

18. Tusnin A.R. Nekotorye voprosy rascheta tonkostennykh stalnykh konstruktsiy [Certain problems of calculating thinwalled steel structures]. Scientific view. 2015. No. 11. Pp. 79-82. (rus)

19. Dey P., Talukdar S. Influence of warping on modal parameters of thin-walled channel section steel beam. Procedia Engineering. 2016. Vol. 144. Pp. 52-59.

20. Latalski J., Warminski J. Dynamics of rotating thin-walled cantilever composite beam excited by translational motion Procedia Engineering. 2016. Vol. 144. Pp. 1039-1046.

21. Tusnin A. Finite element for calculation of structures made of thin-walled open profile rods. Procedia Engineering. 2016. Vol. 150. Pp. 1673-1679.

22. Erdin M.E., Baykasoglu C., Cetin M.T. Quasi-static axial crushing behavior of thin-walled circular aluminum tubes with functionally graded thickness. Procedia Engineering. 2016. Vol. 149. Pp. 559-565.

23. Ruta P., Szybiński J. Lateral stability of bending nonprismatic thin-walled beams using orthogonal series. Procedia Engineering. 2015. Vol. 111. Pp. 694-701.

24. Gorash Y., Comlekci T., MacKenzie D. Comparative study of FE-models and material data for fatigue life
№ 5. С. 44-51.

10. Синельников А.С, Орлова А.В.. Прочность просечнорастяжного профиля: испытания и математическое моделирование // Вестник МГСУ. 2013. № 12. С. 41-54.

11. Лалин В.В., Рыбаков В.А.. Конечные элементы для расчета ограждающих конструкций из тонкостенных профилей // Инженерно-строительный журнал. 2011. №8. С. 69-80.

12. Советников Д.О., Виденков Н.В.,Трубина Д.А. Легкие стальные тонкостенные конструкции в многоэтажном строительстве // Строительство уникальных зданий и сооружений. 2015. № 3. С. 152-165.

13. Айрумян Э.Л., Белый Г.И. Исследование работь стальной фермы из холодногнутых профилей с учетом их местной и общей устойчивости // Промышленное и гражданское строительство. 2010. № 5. С. 41-44.

14. Перельмутер А.В., Сливкер В.И. Устойчивость равновесия конструкций и родственные проблемы. М: Изд-во СКАД СОФТ, 2010. Т. 2. 672 с.

15. Айрумян Э.Л., Каменщиков Н.И. Рамные конструкции стального каркаса из оцинкованных гнутых профилей для одноэтажных зданий различного назначения // Мир строительства и недвижимости. 2006. № 36. С. 9-11.

16. Лалин В.В., Рыбаков В.А., Морозов С.А. Исследование конечных элементов для расчета тонкостенных стержневых систем // Инженерно-строительный журнал. 2012. №1 (27). С. 53-73.

17. Карпиловский В.С., Криксунов Э.3, Перельмутер А.В. Перельмутер M.A. SCAD для пользователя. К: ВВП «Компас», 2000. $332 \mathrm{c}$

18. Туснин A.P. Некоторые вопросы расчета тонкостенных стальных конструкций // Научное обозрение. 2015. № 11. C. $79-82$.

19. Dey P., Talukdar S. Influence of warping on modal parameters of thin-walled channel section steel beam // Procedia Engineering. 2016. Vol. 144. Pp. 52-59

20. Latalski J., Warminski J. Dynamics of rotating thin-walled cantilever composite beam excited by translational motion // Procedia Engineering. 2016. Vol. 144. Pp. 1039-1046.

21. Tusnin $A$. Finite element for calculation of structures made of thin-walled open profile rods // Procedia Engineering. 2016. Vol. 150. Pp. 1673-1679.

22. Erdin M.E., Baykasoglu C., Cetin M.T. Quasi-static axial crushing behavior of thin-walled circular aluminum tubes with functionally graded thickness // Procedia Engineering. 2016. Vol. 149. Pp. 559-565.

23. Ruta P., Szybiński J. Lateral stability of bending nonprismatic thin-walled beams using orthogonal series // Procedia Engineering. 2015. Vol. 111. Pp. 694-701.

24. Gorash Y., Comlekci T., MacKenzie D. Comparative study of FE-models and material data for fatigue life assessments of welded thin-walled cross-beam connections // Procedia Engineering. 2015. Vol. 133. Pp. 420-432.

25. Seangatith S., Thumrongvut J. Behaviors of square thinwalled steel tubed RC columns under direct axial compression on RC core // Procedia Engineering. 2011. Vol. 14. Pp. 513-520.

26. Lei G., Xiaona L. Study on the process of thin-walled titanium alloy tube bending // Procedia Engineering. 2015. Vol. 99. Pp. 1471-1475.

Pavlenko A.D., Rybakov V.A., Pikht A.V., Mikhailov E.S. Non-uniform torsion of thin-walled open-section multispan beams. Magazine of Civil Engineering. 2016. No. 7. Pp. 55-69. doi: 10.5862/MCE.67.6 
assessments of welded thin-walled cross-beam connections. Procedia Engineering. 2015. Vol. 133. Pp. $420-432$.

25. Seangatith S., Thumrongvut J. Behaviors of square thinwalled steel tubed RC columns under direct axial compression on RC core. Procedia Engineering. 2011. Vol. 14. Pp. 513-520.

26. Lei G., Xiaona L. Study on the process of thin-walled titanium alloy tube bending. Procedia Engineering. 2015. Vol. 99. Pp. 1471-1475.

Anna Pavlenko,

+79819875221; anna.pavlenko.1996@yandex.ru

Анна Дмитриевна Павленко, +79819875221;

Vladimir Rybakov,

+7(964)3312915; fishermanoff@mail.ru

эл. почта: anna.pavlenko.1996@yandex.ru

Владимир Александрович Рыбаков, +7(964)3312915;

Artem Pikht,

+7(911)8442933; tamas96@rambler.ru

Egor Mikhailov,

+7(921)9834269; egormi95@mail.ru

эл. почта: fishermanoff@mail.ru

Артём Вячеславович Пихт, +7(911)8442933;

эл. почта: tamas96@rambler.ru

Егор Сергеевич Михайлов,

+7(921)9834269; эл. почта: egormi95@mail.ru

(c) Pavlenko A.D.,Rybakov V.A.,Pikht A.V.,Mikhailov E.S., 2016

Павленко А.Д., Рыбаков В.А., Пихт А.В., Михайлов Е.С. Стесненное кручение многопролетных тонкостенных балок открытого профиля // Инженерно-строительный журнал. 2016. № 7(67). С. 55-69. 